\title{
Developing Optimal Combination of Bulking Agents in an In-Vessel Composting of Vegetable Waste
}

\author{
C. C. MONSON* and A. MURUGAPPAN \\ Department of Civil Engineering, \\ Annamalai University, \\ Annamalainagar, Tamilnadu, India. \\ profam@sify.com
}

Received 16 May 2009; Revised 19 July 2009; Accepted 26 August 2009

\begin{abstract}
The objective of the study is to determine the optimum combination of feed stock components for composting the organic solid waste, a prerequisite for effective microbial degradation and for obtaining quality compost. Combination of dry leaves with locally available bulking agents like sawdust, wood shavings, paddy straw, sugarcane bagasse and rice husk are composted along with vegetable waste in a laboratory scale reactor for the study. The central core of composting process is replicated in controlled conditions in the in-vessel by keeping initial feed stock $\mathrm{C} / \mathrm{N}$ ratio fixed between 30 and 35 . The study is monitored for 14 days for the variations in temperature, $\mathrm{pH}$, moisture and macronutrients $\mathrm{C}$ and $\mathrm{N}$ of the compost. It is found that composting vegetable waste with the combination of paddy straw and dry leaves provided best results of $\mathrm{C} / \mathrm{N}$ ratio of 17.58 confirming that, if right feedstock components are provided, an effective environment for the growth of microorganisms is achieved to accelerate the process to produce a resultant $\mathrm{C} / \mathrm{N}$ ratio acceptable to be used as compost.
\end{abstract}

Keywords: Municipal Solid Waste, Aerobic composting, Bulking agents, In-vessel composting.

\section{Introduction}

Population upsurge, due to rapid industrialization in Indian cities, has led to the generation of thousands of tonnes of municipal solid waste (MSW) daily that are disposed in low-lying areas, without taking any precautions or operational controls. Therefore, Municipal Solid Waste Management (MSWM) has become one of the major environmental problems for all Indian cities that manage the activities associated with generation, storage, collection, transport, processing and disposal of solid wastes ${ }^{1}$. 
The collection and land disposal of solid wastes has become more and more difficult for many municipalities, not only because of the increasing rate of daily per capita waste generation ${ }^{2}$ from 0.2 to $0.6 \mathrm{~kg} \mathrm{day}^{-1}$, but also due to the steadily increasing cost of land and its shortage in city outskirts ${ }^{3}$. Though, the recycling of MSW has been started to a large extent in developing countries like India, it remains still in its infant stage compared to the developed countries such as U.S.A, European countries and $\mathrm{Japan}^{4}$. Solid waste which is usually disposed as landfills pollute the soil, groundwater by its leachates and also by the gases evolved during decomposition, whereas the atmosphere gets directly polluted by the release of green house gases due to incineration of the solid wastes ${ }^{5,6}$.

It has been found approximately that $134 \mathrm{~kg} / \mathrm{ha}$ nutrients are exhausted every year in India from the soil due to the raising of different crops but the amount of input ( $\mathrm{N}, \mathrm{P}$ and $\mathrm{K})$ to the soil is only $74 \mathrm{~kg} / \mathrm{ha}$ by chemical fertilizers. The net result is that the soil is regularly being depleted of these essential nutrient elements on a continuous basis. Composting of degradable solid wastes not only addresses the problem of MSWM but also results in quality end products that have high fertility value ${ }^{7}$.

Centralized Composting in windrows using forced aeration or turning or by passive aeration could be a good alternative where land is available in plenty, even though it involves large investments ${ }^{8}$ but for managing large quantities of organic solid wastes, decentralized composting is the only eco-friendly option as it provides an efficient and economical way of disposal. The development of In-vessel technique is found to be a better alternative for decentralized units as this rotary vessel provides oxygen and nutrients in controlled atmosphere and also hastens the process within 2 to 3 weeks to degrade the organic waste fraction of $\mathrm{MSW}^{9}$.

\section{Composting process}

Composting is the biological decomposition of wastes consisting of organic substances of plant or animal origin under controlled conditions to a state sufficiently stable for nuisance-free storage and utilization ${ }^{10,11}$.To produce high quality compost, it becomes essential to optimize, from the start to the end of the whole process by managing the feed components and also the process parameters like temperature, moisture content, bulk density, aeration rates and $\mathrm{C} / \mathrm{N}$ ratio ${ }^{12}$. For proper microbial degradation, the initial $\mathrm{C} / \mathrm{N}$ ratio has to be kept in between ${ }^{13} 40$ to 20 . Carbon serves primarily as a food source and Nitrogen the primary constituent of protein. To bring to an optimum $\mathrm{C} / \mathrm{N}$ ratio nearer to 30-35, bulking agents like saw dust, wood shavings, sugar cane bagasse, dry leaves, paddy straw, paddy husk may be added as an amendment, as they give enough carbon source and also reduce the excess moisture content, increasing the porosity and integrity of the organic solid matrix.

To assure proper rate of biodegradation, moisture should be in the range of $50 \%$ to $70 \%$ throughout the degradation process. If excess moisture is found, it reduces the available oxygen supply, resulting in anaerobic pockets within the compost, releasing odorous compounds. Air is to be supplied in order to provide oxygen facilitating the growth of microorganisms and also to drive away the hot gases ${ }^{14}$.

The temperature of the substrate within the reactor varies according to the type and size of the microorganism community resident therein. The mesophilic microorganisms that are present become less competitive as the temperature rises above $40{ }^{\circ} \mathrm{C}$, and thermophilic microorganisms take over. Current Environmental Protection Agency regulations require temperatures in excess of $55{ }^{\circ} \mathrm{C}\left(131^{\circ} \mathrm{F}\right)$ for at least four hours to destroy pathogens within 
the composting reactor ${ }^{15}$. Sanitization of the composting process is achieved by the thermophilic temperatures which kill many of the pathogens that may be initially present in the mixture. Optimum air and moisture contents are also necessary in sustaining adequate microbial populations active ${ }^{15}$. Carbohydrates are structurally simplest and degrade faster than others and they do in the following order: Carbohydrates $>$ hemi-cellulose $>$ cellulose $>$ chitin $>$ lignin. Thus, materials such as fruit and vegetables with higher concentrations of simple carbohydrates are more rapidly compostable than leaves, bark and wood which contain cellulose, hemi-cellulose and lignin ${ }^{16}$. Composting systems which generally used worldwide are: Naturally aerated windrow system, Forced aerated static piles, Tunnel system and Rotating drums or cylinders (in-vessel systems).

Of all the above mentioned methods, the most adaptable to Indian conditions is the closed in-vessel composting, which generally derives the techniques both from the windrow and aerated pile methods and is a combined effort in a controlled atmosphere to overcome the deficiencies and problems encountered by them to convert the entire organic solid waste with suitable amendments of organic manure within a short duration ${ }^{17}$ Donahue et $a l^{18}$ demonstrated that food waste was successfully composted with saw dust and mulch chips in an In-vessel system within 14 days, after which the product was placed in windrows for curing. If the reactor performance does not meet the desired stability required for compost then the partially stabilized material may be required to be further cured in windrows to achieve maturity ${ }^{14}$. Bulking agents are provided in order to have stability, integrity and porosity to the solid matrix during the process of composting. Composting of vegetable solid waste, with cow dung and different combinations of bulking agents were carried out in an in-vessel so that an optimal combination of bulking agents with vegetable market waste is found out during composting to produce a quality end product.

\section{Experimental}

The waste sample was collected from the waste generated from the main vegetable market of Chidambaram, located at the centre of the town, which contributes a major share of nearly 10-15 tonnes of organic waste out of the total daily generation of 32-39 tones of MSW from the entire town. The characteristics of the waste were found to vary from season to season. Physical and chemical characteristics of vegetable wastes and bulking agents used in the study were determined. The bulk density and the moisture content of vegetable wastes range about $300-400 \mathrm{~kg} / \mathrm{m}^{3}$ and $70 \%-80 \%$ respectively. The monthly variations of the vegetable waste were significant with respect to their moisture content and their $\mathrm{C} / \mathrm{N}$ ratios. The $\mathrm{C}$ on a dry weight basis (dwb) was found to vary during April to November. The mean monthly $\mathrm{C}$ of $36.3 \%( \pm 0.77 \%)$ in May was higher than that of June, July and August at $32.4 \%( \pm 4.05 \%)$. The TKN (dwb) of $0.9 \%( \pm 0.11 \%)$ in May also increased to $1.4 \%( \pm 0.30 \%)$ than in June, July and August. Thus, the $\mathrm{C} / \mathrm{N}$ ratio was found to decrease from 36.4 in May to 32.4 in June. The $\mathrm{C} / \mathrm{N}$ ratio of vegetable waste in the summer (April-August) is balanced enough to be composted without any correction from the bulking agent, while that of May is slightly high compared to the recommended $\mathrm{C} / \mathrm{N}$ ratio of 30-35 for the effective composting of vegetable waste ${ }^{2}$. The experiment was carried out in the month of June to get the optimum result.

The moisture content of the waste collected was relatively high due to vegetables and it was sorted manually to ensure that it contained no oversized and undesirable materials. The waste then was shredded manually to a size of $20-30 \mathrm{~mm}$ to give a better exposure for microbial treatment and to expedite the ensuing metabolic process. The main function of the 
bulking agents is to increase the proportion of free airspace and to assist in providing optimum moisture content, besides satisfying the feedstock requirements before composting. Carbon which plays an important role in Nitrogen immobilization is provided in plenty through these bulking agents as microbes waste nearly ${ }^{19}$ from $60 \%$ to $70 \%$ of the $\mathrm{C}$ as $\mathrm{CO}_{2}$. Bulk density should be low enough (less than $40 \mathrm{lb} / \mathrm{ft}^{3}$ ) to allow for good aeration. Dense manures and sludge can be lightened by adding bulking agents, such as wood chips, corn cobs, and straw ${ }^{20}$. Using sawdust and bagasse as bulking agents, $\mathrm{pH}$ profile rose from 5.5 to 6.8 within two weeks, whereas in that using cassava pulp dropped down towards the end of the experiment ${ }^{21}$. Bulking agents which are locally available in plenty almost in all seasons and having low bulk density and high moisture absorbing capacity namely, leaves, saw dust, bagasse, wood shavings, rice husk and paddy straw were used in this study.

Six trials of composting vegetable solid waste and cow dung were carried out with the following combinations of bulking agents provided in order to have stability, integrity and porosity to the solid matrix during composting. These trial combinations were Mix-1 (Control without any bulking agents), paddy straw and dry leaves in Mix-2, wood shavings and dry leaves in Mix-3, bagasse and dry leaves in Mix-4, rice husk and dry leaves in Mix-5 and saw dust and dry leaves in Mix-6. The mix combinations with different bulking agents are given in the Table 1.

Table 1. Bulking agents in different mix combinations.

\begin{tabular}{lcccccc}
\hline \multirow{2}{*}{ Materials* } & \multicolumn{5}{c}{ Mix ratio } \\
\cline { 2 - 6 } & $\begin{array}{c}\text { Mix-1 } \\
\text { (Control) }\end{array}$ & Mix-2 & Mix-3 & Mix-4 & Mix-5 & Mix-6 \\
\hline $\begin{array}{l}\text { Vegetable waste: } \\
\text { Cow dung: } \\
\text { Bulking agents }\end{array}$ & $5.32: 1.05: 0$ & $5.20: 1.14: 1$ & $5.91: 1.17: 1$ & $5.04: 1.04: 1$ & 5.54:0.85:1 & 4.93:1.06:1 \\
\hline
\end{tabular}

Mix-1: Without any bulking agent; Mix-2: Paddy straw and dry leaves; Mix-3: Wood shavings and dry leaves Mix-4: Bagasse and dry leaves; Mix-5: Rice husk and dry leaves; Mix-6: Saw dust and dry leaves.

*The above ratios are by wet weight basis

The combination of dry leaves mainly of nettilingam tree, known in its botanical name as Polyalthia longifolia from the family of Annaonaceae, was added with other bulking agents as they were found in plenty, good in moisture absorbance and provides good free air space at the initial stages. Cow dung was added to serve as inoculum for the start up of the process in each trial as well as to bring the feedstock $\mathrm{C} / \mathrm{N}$ ratio within the acceptable range. The bulking agents selected are high in moisture absorbance $(75 \%$ $85 \%)^{14}$; have a $\mathrm{pH}$ value ranging between 4.5 and 7.5 . The resultant $\mathrm{pH}$ value of al the mixes tried were in the range of 5.5-7.5. It was found that the saw dust had a higher $\mathrm{C} / \mathrm{N}$ ratio than that of the other bulking agents, which had to be supplemented with selected higher nitrogen content materials. The moisture content was found to be balanced at a range of $60-70 \%$ at the start of the trials and could be added in the course of composting if it goes below $50 \%$.

The laboratory scale bio-reactor fabricated was a cylindrical vessel used for the bio conversion of the wastes. It had a Fibre Reinforced Plastic (FRP) drum of capacity of 50 litres with vinyl ester resin material coat given on the inside surface to take care of the load intensity, as well as the temperature and chemical changes taking place at the time of the waste conversion process. The airflow was regulated to achieve the required flow so that optimal quantity of air was supplied to degrade the substrate. The process was totally self heating, and air was supplied by an aerator at the rate of $10 \mathrm{~L} / \mathrm{min}$ initially to cater to the 
volume of substrate inside the drum and decreased progressively up to the curing stage so that a minimum of 5\% of oxygen is maintained in the substrate for the growth of microorganisms ${ }^{10,11}$. The vessel was belt driven at a slow speed of about $3 \mathrm{rpm}$, with a $0.5 \mathrm{HP}$ motor facilitated by a reduction wheel pulley arrangement. The rotation was given for every three hours with an hour break for rest and even distribution of microbial aerobic organisms. However the air flow was maintained continuous throughout the period. Even when a highly putrescible waste is processed using a fairly effective aeration system, a minimum of 12-14 days of active composting time is necessary for a relatively short residence time in the bioreactor $^{10,11}$. Composting was carried out for 14 days and brought to an end when temperature declined close to ambient. Simultaneously physical investigation was carried out, taking a sample of $100 \mathrm{gm}$ of waste every two days to find its degree of maturity.

Currently, indirect measures for determining the concentration of biodegradable organic matter are used and most of them are based on respiration indices (oxygen consumption or carbon dioxide production) but the direct measurement of chemical parameters Total Organic Carbon (TOC) and Total Kjeldhal Nitrogen (TKN) will be useful in better prediction of the rate of degradation ${ }^{19}$. The initial feedstock components of the trial mixes were optimized to have a $\mathrm{C} / \mathrm{N}$ ratio around 35 for effective growth of microorganisms.

The $\mathrm{pH}$ had to be adjusted in Mix-3 (wood shavings and dry leaves as bulking agents) by adding little bit of lime to neutralize, when it had gone very low during the process to prevent the slowdown of the process. The drying up of moisture content during the $4^{\text {th }}$ and $5^{\text {th }}$ day in most of the trials due to the constant air flow had to be reduced progressively to maintain the temperature and the moisture content had been supplemented for ensuring the growth of microorganisms.

The moisture content of the trial mix samples were measured after drying at $105^{\circ} \mathrm{C}$ for overnight. The dried sample were ground and then used in the analysis. The Volatile Solids (VS) was measured after igniting the sample in a muffle furnace at $550{ }^{\circ} \mathrm{C}$ for 2 hours. Total Organic Carbon (TOC) was calculated by the formula ${ }^{19,14}$ TOC $=(100 \%$ Ash $) / 1.8$. Total Kjeldahl Nitrogen (TKN) was measured by semi-micro and macro Kjeldahl method ${ }^{22}$. Moisture content, temperature, $\mathrm{pH}$ and Electrical Conductivity were measured using the multipronged probe of Hitachi make.

\section{Results and Discussion}

Substrate temperature is one of the main parameters to ensure effective composting. Figure 1 shows the variation of substrate temperature with time duration since the commencement of composting process for different trial mixes considered in the study. The temperature of the substrate at the beginning of the composting process in all mixes was in the range 34.5 to $37.5^{\circ} \mathrm{C}$. From Figure 1, it is found that the temperature of the substrate has a rapidly increasing trend during the first 3 days for all mixes except mix-1. In case of mix-1, the rise in temperature is relatively very gradual. This could be attributed to the lack of free air space because of less porosity. The peak temperature was attained at the end of the third day for all mixes except mix- 6 and mix- 1 . In case of mix-6, the maximum temperature was attained at the end of the fourth day, while in mix-1 the maximum temperature was attained at the end of the sixth day from the commencement of composting. Of all the mixes, mix-2 attained the maximum temperature of $63.5^{\circ} \mathrm{C}$ at the end of the third day. The maximum temperatures attained by mix- 3 were also comparable to that of mix-2 at $61{ }^{\circ} \mathrm{C}$. Maximum temperatures of $58.5,56.5$, and $58.5^{\circ} \mathrm{C}$ were attained respectively in case of mix- 4 , mix- 5 and mix- 6 . The maximum temperature attained by mix-1 was much lower at $42{ }^{\circ} \mathrm{C}$ when compared to those obtained by other mixes. 


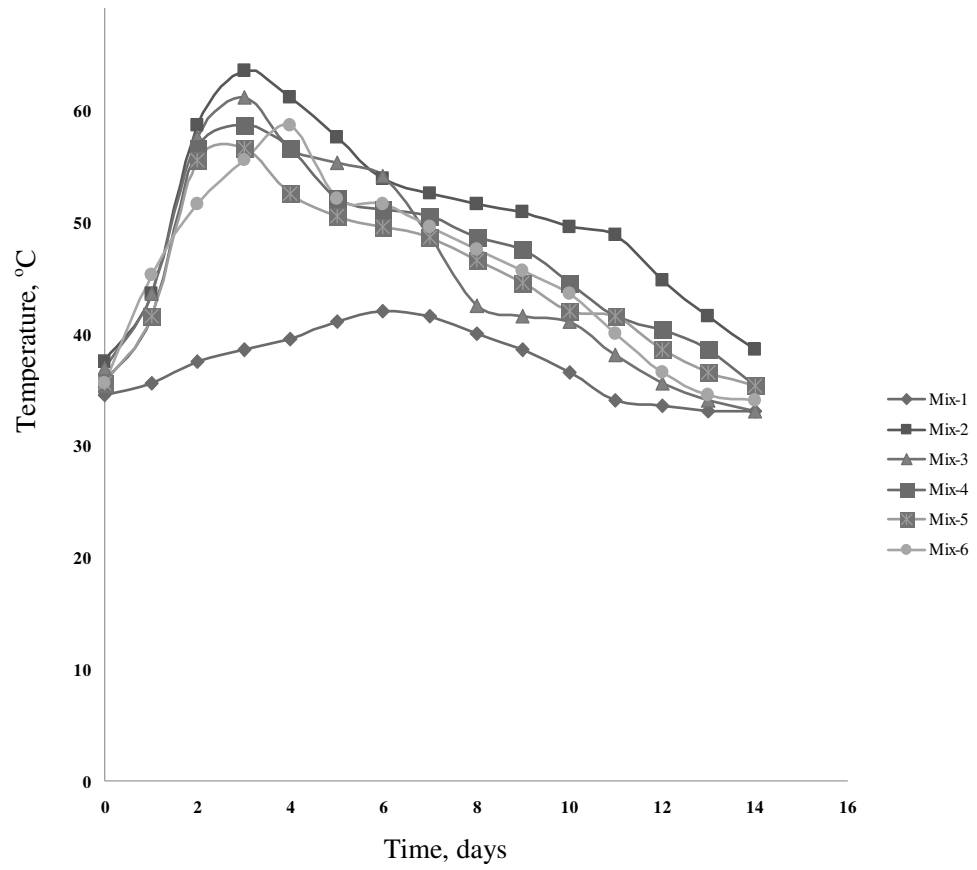

Figure 1. Variation of substrate temperature.

The mix-1 had not crossed the mesophilic range of temperature because of its initial higher bulk density and lower porosity ${ }^{13}$. After reaching the peak temperature, the substrate temperature started to fall for all mixes with the rate of fall found to be less than the rate of increase in temperature in all mixes except mix-3. In mix-2 and mix-3, the falling temperature was found to be above $55^{\circ} \mathrm{C}$ till the end of the sixth day after the commencement of composting. These two mixes satisfy the conditions laid out by USEPA ${ }^{15}$ guidelines for quality compost. While in mixes 4,5 and 6 , the substrate temperature fell below $55^{\circ} \mathrm{C}$ after the end of the fourth day/third day.

Chopped paddy straw and dry leaves used as bulking agents in mix-2 have a high water absorption capacity of more than 80 per cent, neutral $\mathrm{pH}$ and moderate $\mathrm{C} / \mathrm{N}$ ratio ${ }^{5,6}$ of about 50 . At the end of 14 days of composting process, the $\mathrm{C} / \mathrm{N}$ ratio of mix 2 reduced to 17.58 while $\mathrm{C} / \mathrm{N}$ ratios of $19.35,22.08,22.21,26.98$ and 29.49 were attained for mixes $3,5,4,6$ and 1 respectively. The bulking agents wood shavings and dry leaves used in mix-3, even though were found to be acidic ${ }^{5,6}$ and showed a lack of stability after absorbing moisture at the initial stage had produced a $\mathrm{C} / \mathrm{N}$ ratio of 19.35 because of addition of lime. Bagasse and dry leaves used as bulking agents in mix-4, even though were found to provide structural stability in the initial stage of composting after absorbing moisture did not produce the required reduction in $\mathrm{C} / \mathrm{N}$ ratio. This could be attributed to the higher lignin content in bagasse which takes a longer duration for bio-degradation and less nitrogen content ${ }^{23}$. Rice husk used as bulking agent in mix-5 did not provide adequate porosity and hence resulted in $\mathrm{C} / \mathrm{N}$ ratio of 22.08 . In case of saw dust used in mix-6, the free air space required for effective degradation of waste was not adequate due to absorption of moisture. This resulted in slow down of biological activity and resulted in a high $\mathrm{C} / \mathrm{N}$ ratio of 26.98 at the end of fourteen days of composting. Linear equations were fitted to the reduction in $\mathrm{C} / \mathrm{N}$ ratio with respect to time duration for the different trial mixes of composting. The results are shown in Table 2. 
Table 2. Linear equation fitted to reduction in $\mathrm{C} / \mathrm{N}$ ratio with time duration for different mixes of composting

\begin{tabular}{lcc}
\hline \multicolumn{1}{c}{ Mixes of composting } & Linear Equation fitted & $\begin{array}{c}\text { R-squared } \\
\text { value }\end{array}$ \\
\hline Mix-1 (Without any Bulking agents-Control) & $\mathrm{C} / \mathrm{N}=-0.463\left(\mathrm{t}_{\mathrm{d}}\right)+34.83$ & 0.903 \\
Mix-2 (Paddy straw and Dry leaves) & $\mathrm{C} / \mathrm{N}=-1.134\left(\mathrm{t}_{\mathrm{d}}\right)+34.52$ & 0.989 \\
Mix-3 (Wood shavings and Dry leaves) & $\mathrm{C} / \mathrm{N}=-1.152\left(\mathrm{t}_{\mathrm{d}}\right)+36.60$ & 0.964 \\
Mix-4 (Bagasse and Dry leaves) & $\mathrm{C} / \mathrm{N}=-0.890\left(\mathrm{t}_{\mathrm{d}}\right)+33.83$ & 0.935 \\
Mix-5 (Rice husk and Dry leaves) & $\mathrm{C} / \mathrm{N}=-0.962\left(\mathrm{t}_{\mathrm{d}}\right)+35.58$ & 0.988 \\
Mix-6 (Saw dust and Dry leaves) & $\mathrm{C} / \mathrm{N}=-0.671\left(\mathrm{t}_{\mathrm{d}}\right)+36.86$ & 0.983 \\
\hline
\end{tabular}

The rate of reduction in $\mathrm{C} / \mathrm{N}$ ratio which is indicative of the rate of decomposition of the waste is found to be maximum for Mix-3. But, the variation in the rate of reduction in $\mathrm{C} / \mathrm{N}$ ratio between the two mixes, Mix-2 and Mix-3, was not much and that they can be considered insufficient. Hence, the ranking of mixes in terms of rate of reduction of $\mathrm{C} / \mathrm{N}$ ratio indicated by the slope of the fitted linear equation is in the order: Mix- $3<\operatorname{Mix}-2<$ Mix-5 < Mix- $4<$ Mix- $6<$ Mix- 1 . However, the maximum reduction of $\mathrm{C} / \mathrm{N}$ ratio occurred in case of Mix-2 (Figure 2). Low $\mathrm{C} / \mathrm{N}$ ratio ensures effective organic matter decomposition and stabilization during composting. The ranking of mixes according to the total reduction in $\mathrm{C} / \mathrm{N}$ ratio is found to be in the order: Mix- $<$ Mix-3 $<$ Mix- $5<\operatorname{Mix}-4<\operatorname{Mix}-6<\operatorname{Mix}-1$. Hence, it is concluded that paddy straw and dry leaves are used as bulking agents (Mix-2) is found to be the best combination in composting of vegetable waste.

\section{Conclusion}

The falling temperature after attaining peak temperature at the end of third day was found to be above $55^{\circ} \mathrm{C}$ till the end of the sixth day after the commencement of composting for mixes 2 and 3 . These two mixes satisfy the conditions laid out by USEPA ${ }^{15}$ guidelines for quality compost. Composting of vegetable waste with the combination of paddy straw and dry leaves has provided the maximum reduction in $\mathrm{C} / \mathrm{N}$ ratio equal to 17.58 at the end of 14 days of composting. This confirms that if right feedstock components are provided, an effective environment for the growth of microorganisms is achieved to accelerate the process to produce a resultant $\mathrm{C} / \mathrm{N}$ ratio acceptable to be used as compost.

\section{References}

1 Mufeed Sharholy, Kafeel Ahmad, Gauhar Mahmood and Trivedi R C, Waste Management, 2008, 28, 459-467.

2 CPHEEO, Manual on Municipal Solid Waste Management, GOI, New Delhi, 2000, 262-409

3 Michael Gundry, Chris Visser, Water Environment Association of Ontario $36^{\text {th }}$ Annual Technical Symposium, 2007.

4 Agarwal Ankit, Ashish Singhmar, Mukul Kulshrestha and Atul K Mittal, Resources, Conservation and Recycling, 2005, 44, 73-90.

5 Adhikari Bijaya K, Barrington Suzelle, Jose Martinez and Susan King, Waste Management, 2009, 29(1), 197-203, doi:10.1016/ j.wasman.2008.04.001.

6 Adhikari Bijaya K, Suzelle Barrington, Jose Martinez and Susan King, Waste Management, 2008, 28, 795-804

7 Ghosh C, Biores Technol., 2004, 93, 71-75.

8 Salona M L, Iriarte F, Ciria P and Negro M J, J Agric Eng Res., 2001, 79(3), 317-329. 
9 Kalamdhad Ajay, Absar S and Kasmi A, Waste Management and Research, 2009, 27, 129-137

10 Diaz L F, Savage G M, Eggerth L L and Golueke C G, Composting and Recycling Municipal Solid Waste, Lewis Publishers, Inc., 1993.

11 Diaz L F, Savage G M, Eggerth L L and Golueke C G, Compost Science and Technology, Lewis Publishers, Inc., 1993.

12 Mohee Romeela and Ackmez Mudhoo, Powder Technology, 2005, 155, 92-99.

13 Rynk R et al., On-Farm Composting Handbook, NRAES, Ithaca, NY, 1992.

14 Haug R T, The practical handbook of compost engineering, Lewis Publishers, Florida, USA, 1993.

15 USEPA, Part503 Rule-Land Application of Biosolids, 1994, http://www.epa.gov/owm/ biosolids/503pe.

16 Cooperband L R, The Art and Science of Composting [online], 2002, http://www.cias.wisc.edu/wp-content/uploads/2008/07/artofcompost.pdf.

17 Mbuligwe S E, Kassenga G R, Kaseva M E and Chaggu E J, Resources, Conservation and Recycling, 2002, 36, 45-59.

18 Donahue D W, Chalmers J A and Storey J A, Compost Science and Utilization, 1998, 6(2), 75-81.

19 Barrington S, Choiniere D, Trigui M and Knight W, Biosys Eng., 2002, 81(4), 433-441.

20 Dana O Porter, Utilization of Organic Wastes: On-farm Composting; http://www.wvu.edu/ Agexten/ageng/resource/utiliow.htm.

21 Sudarut Tripetchkul, Chuenjit Kinganara and Pawinee Chaiprasert, The $5^{\text {th }}$ AsiaPacific Biochemical Engineering Conference and The $11^{\text {th }}$ Annual Meeting of the Thai Society for Biotechnology, 1999.

22 APHA, Methods for the Examination of Water and Wastewater, 1995, Washington DC.

23 Eklind Y and Kirchmann H, Biores Technol., 2000, 74, 115-124. 


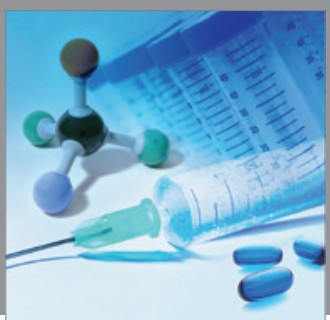

International Journal of

Medicinal Chemistry

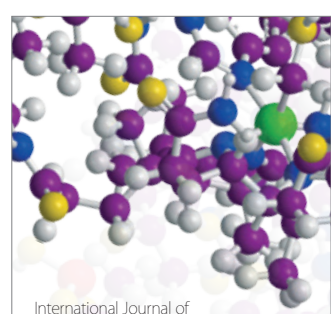

Carbohydrate Chemistry

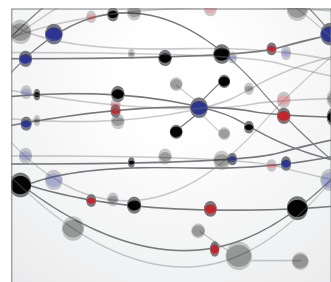

The Scientific World Journal
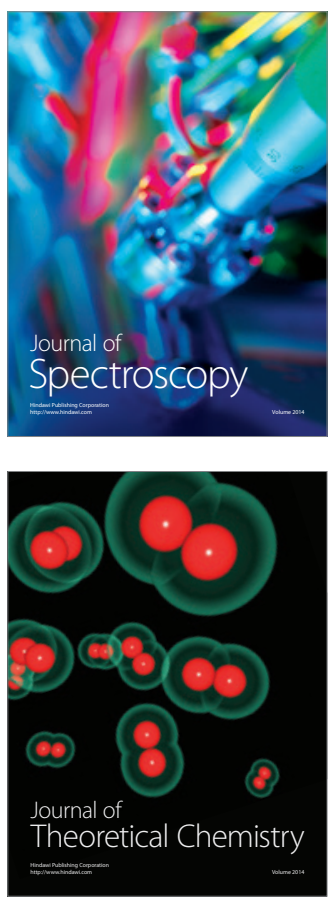
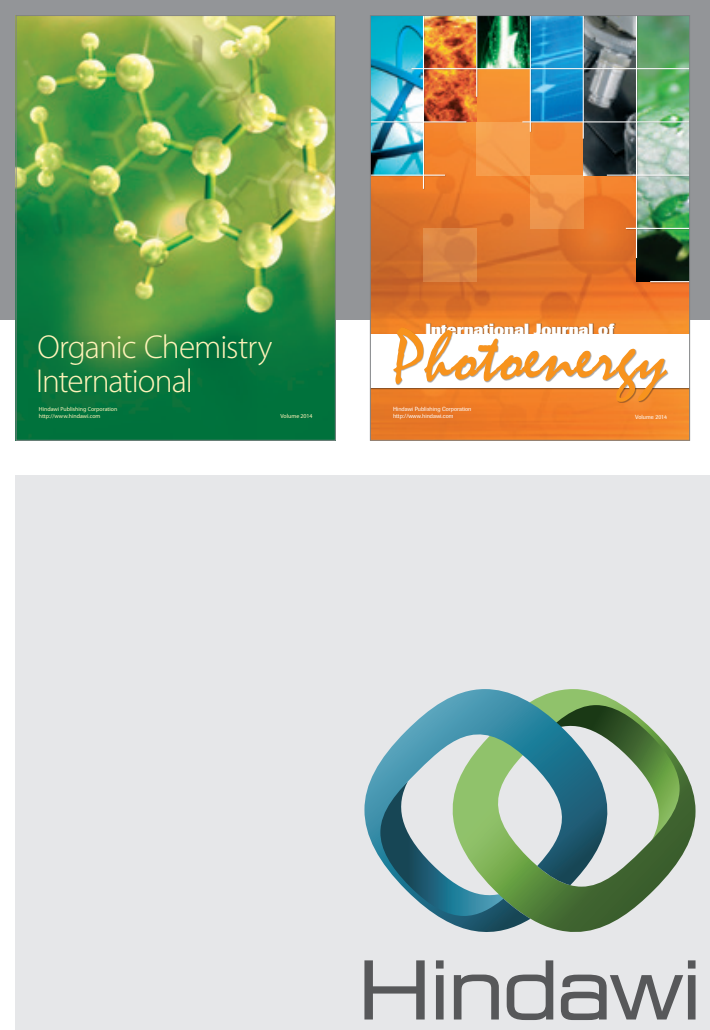

Submit your manuscripts at

http://www.hindawi.com
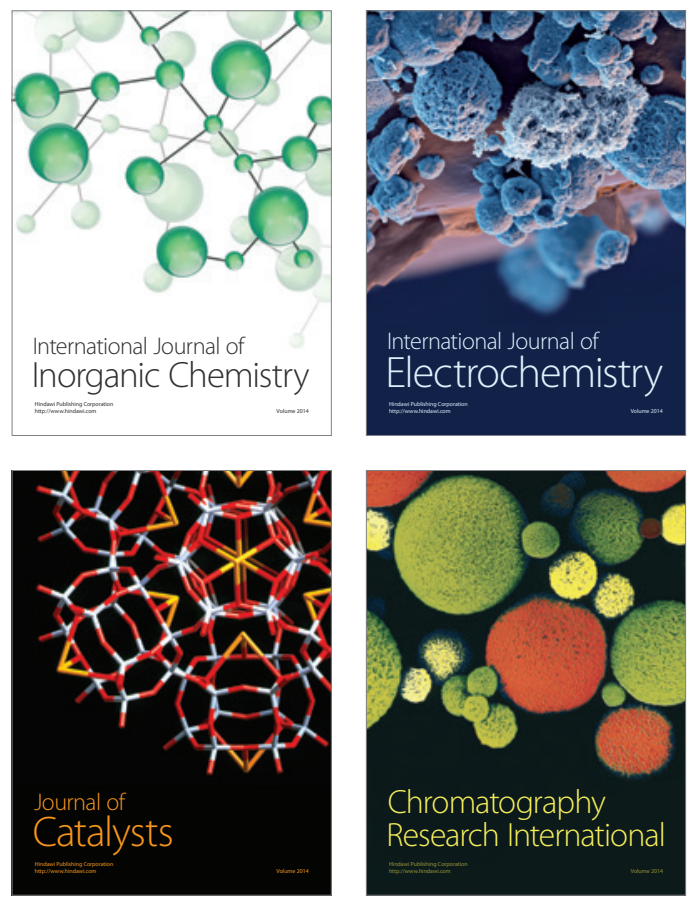
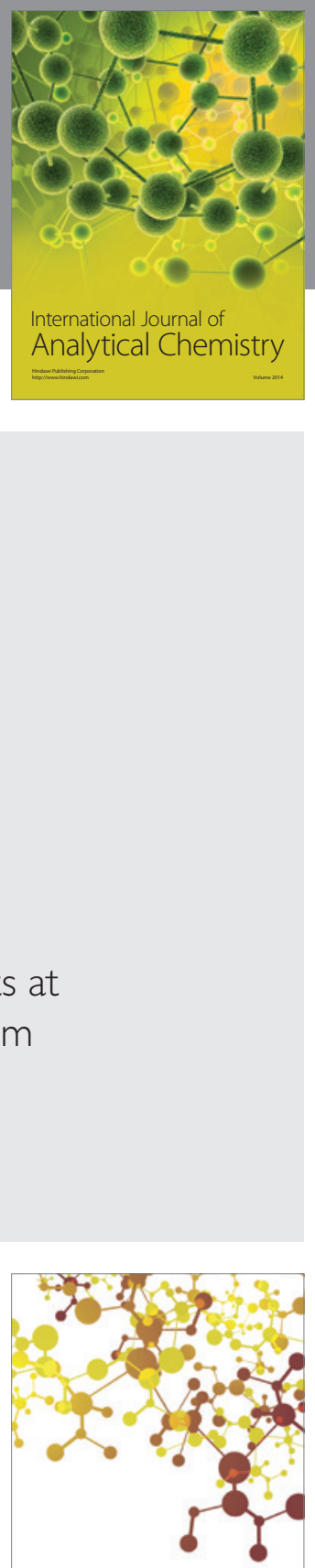

Journal of

Applied Chemistry
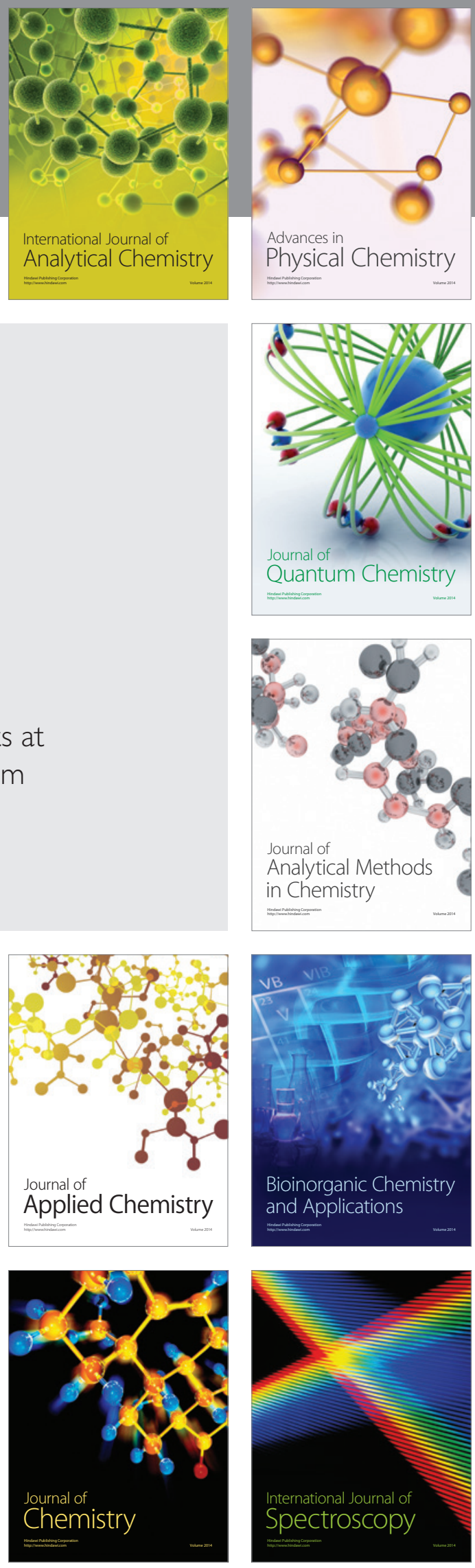